\title{
ASSESSMENT OF GEOTECHNICAL SEISMIC HAZARD OF THE DHAMAR CITY, YEMEN*
}

\author{
Adel A. Al-Raziqi ${ }^{1 * *}$, Ali Hussein A. Al-Sanabani ${ }^{2}$, \\ M.R. Janardhana ${ }^{3}$, Ahmed A. Al-Aydrus ${ }^{4}$ \\ ${ }^{2,3}$ Dept. of Earth Science \& R.M, Yuvaraja's College, University of Mysore, Yemen. \\ ${ }^{4}$ Dept. of Earth Sciences, Faculty of Science,Sana'a University, Yemen.
}

${ }^{1}$ Dept. of Civil Engineering, Dhamar University, Yemen

\begin{abstract}
The objective of this paper is to assess and present the geotechnical seismic hazard in the Dhmarar city, Yemen. During the present study assessment for the geotechnical seismic hazard was carried out in an area of $100 \mathrm{~km}$ radius around Dhamar city. Based on the Geotechnical data obtained for this study, Seismotectonic maps are constructed showing the major lineaments to trend in NW-SE, NE-SW and SWWNEE directions that attribute to the general directions of the axial of the Red Sea and the Gulf of Aden. The earthquake catalogue of the region facilitated the classification of seismicity of the region into three major seismic periods. The $b$ value is classified as low and is the characteristic of the continental rift zone that corroborates well with the geological evolution of the study area. Isointensity zoning and PGA maps with two epicentral distances of zero and $50 \mathrm{~km}$ were constructed. The Isointensity maps indicated that the intensity of the entire study region ranges from II to VIII on MMI scale. Micro level study carried out in the immediate vicinity of Dhamar city indicates the region to be slightly hazardous whose intensity ranges from II to III on MMI scale. The PGA values for the region and the area under investigation vary from zero to 500 and 20 to $180 \mathrm{~cm} / \mathrm{sec}^{2}$ respectively. Based on the geotechnical field evidences and statistical data, the relation between seismicity, volcanicity and thermal springs are strong.
\end{abstract}

KEY WORDS: Geotechnical seismic hazard, peak ground acceleration, Dhamar city, Yemen.

\section{ÉVALUATION DES ALEAS SISMIQUES GEOTECHNIQUE DE LA VILLE DE DHAMAR, YEMEN}

\section{RÉSUMÉ}

L'objectif de cette étude est d'évaluer et de présenter le risque géotechnique sismique dans la ville Dhmarar, au Yémen. Au cours de la présente étude d'évaluation pour le risque sismique géotechnique a été réalisée dans une zone d'un rayon de $100 \mathrm{~km}$ autour de la ville de Dhamar. Sur la base des données géotechniques obtenus pour cette étude, les cartes sont construites sismotectoniques montrant les linéaments majeurs à la tendance en NW-SE, NE-SW et SNT-NEE directions qui attribuent aux directions générales de la axiale de la mer Rouge et le golfe d'Aden. Le catalogue des séismes de la région a facilité la classification de la sismicité de la région en trois grandes périodes sismiques. La valeur b est classé comme faible et est la caractéristique de la zone de rift continental qui corrobore bien avec l'évolution géologique de la zone d'étude. Isointensity cartes de zonage et de la PGA avec deux distances épicentre de zéro et $50 \mathrm{~km}$ ont été construits. Les cartes Isointensity indiqué que l'intensité des plages entières région d'étude à partir de II à VIII sur l'échelle MMI. Étude au niveau micro effectuée dans le voisinage immédiat de la ville Dhamar indique la région à peu polluant dont l'intensité varie de II à III sur l'échelle MMI. Les valeurs PGA pour la région et la zone objet de l'enquête varie de zéro à 500 et 20 à $180 \mathrm{~cm} / \mathrm{sec} 2$ respectivement. Sur la base des preuves sur le terrain géotechniques et les données statistiques, la relation entre la sismicité, le volcanisme et les sources thermales sont forts.

MOTS CLÉS: géotechnique aléa sismique, l'accélération maximale du sol, Dhamar ville, au Yémen.

\footnotetext{
* Received: 15/8/2012, Accepted: 4/9/2012 (Original Paper)

** Contact author (raziqi@gmail.com)
} 


\section{INTRODUCTION}

Yemen is characterized by active seismicity and volcanic activity. There are historical accounts of strong seismic events since the $13^{\text {th }}$ century, with about $20-30$ year recurrence interval (Girdler, 1970; Mckenzie et al., 1970, Alsinawi and Alaydrus, 1999). Mention could be made of Aden's (1387), Al Moka (1394), Sana'a (1666), AlHayma (1873-74), Moka (1896-97), Waylan (1909) earthquakes (Matthews, 1984; Minissale et al., 2007) which severely affected the economy of Yemen and killed many people as well as caused a lot of damage to the public property. However, the earthquake felt in various regions of Yemen and Saudi Arabia in the year 1941 is considered the most devastating, causing major damages in the area extending from Sana'a to Jizan. This earthquake has although been considered largest in Yemen (Al Munifi, 1993; and Al Aydrus, 1997) in its recent history of seismic events, the most destructive event with a body wave magnitude of $6(\mathrm{mb}=6)$ was that took place in Dhamar in 1982, (Minissale et al., 2007) claiming the lives of more than 3000 people, affecting around 300 villages and causing a loss of $\$ 2$ billion to the exchequer.

Tectonically, Yemen is located in relatively active seismic zone and the seismic activity is more pronounced along the spreading ridges, but a low level of seismicity, characterized by small-to moderate-size events, occurs within the Arabian Plate within 200 to $300 \mathrm{~km}$ of the axis of the Red Sea in Yemen, and extends into adjacent areas southward (Alsinawi \& Al Aydrus, 1999). The seismicity of the Red Sea was interpreted in relation to the African rift, the Gulf of Aden and the Arabian Sea.

Agha, based on his study in 1983, presented a seismic zoning map for the Northern Province of Yemen. The province was divided into four seismic zones. The first (active) zone is located in the central plateau. The second zone covers Tihama plain and Al-Jawf Ramlat Sabata'ayn; the region is characterized by tectonism in the Late Neogene. The third zone encompasses the western and southern regions; the area is more stable, and mild seismicity in this region is attributed to volcanism. The fourth (safe) zone covers the basement area. Further, Alsinawi \& Hamad (1991) gave a seismic zoning map of Yemen and surrounding regions. They divided the whole area into four zones with seismic intensity ranging between III-IX. Moreover, Yemen is classified into two major seismogenic zones namely (1) the Red Sea-Gulf of Aden seismogenic zone and (2) the Continental Yemen seismogenic zone (Alsinawi \& Hamad, 1991). The Continental Yemen seismogenic zone has been further subdivided, into Yemen Plateau Seismogenic Subzone and the Hadramout Seismogenic Subzone (Thenhaus et al., 1989).

The knowledge of the state of seismicity in Yemen was quite limited before the 1982 Dhamar earthquake. Since then, scarce field seismological data have been collected from Dhamar and few other parts in Yemen by many investigators. The significant earthquake swarms that began in Al-Udayn earthquake (M: 4.2) on November 1991 were the starting point to more detailed seismological monitoring in Yemen (AlSalim \& Saleh, 1996).

This paper examines the vulnerable areas for seismic hazard in and around Dhamar city through the determination of seismic intensity and the peak ground acceleration (PGA).

\section{STUDY AREA}

Republic of Yemen (Arabian Felix) is situated in the southern part of Arabian Peninsula, between $12^{\circ}-19^{\circ} \mathrm{N}$ Latitude and $42^{\circ}-55^{\circ} \mathrm{E}$ Longitude. The study area (terrain surrounding Dhamar city) is situated in the middle of the Central Highlands of Yemen, $100 \mathrm{~km}$ to the south of the capital city of Yemen, Sana'a city. During the present study geotechnical seismic hazard assessment was carried out in an area of 100 $\mathrm{km}$ radius around Dhamar city (Fig. 1). 


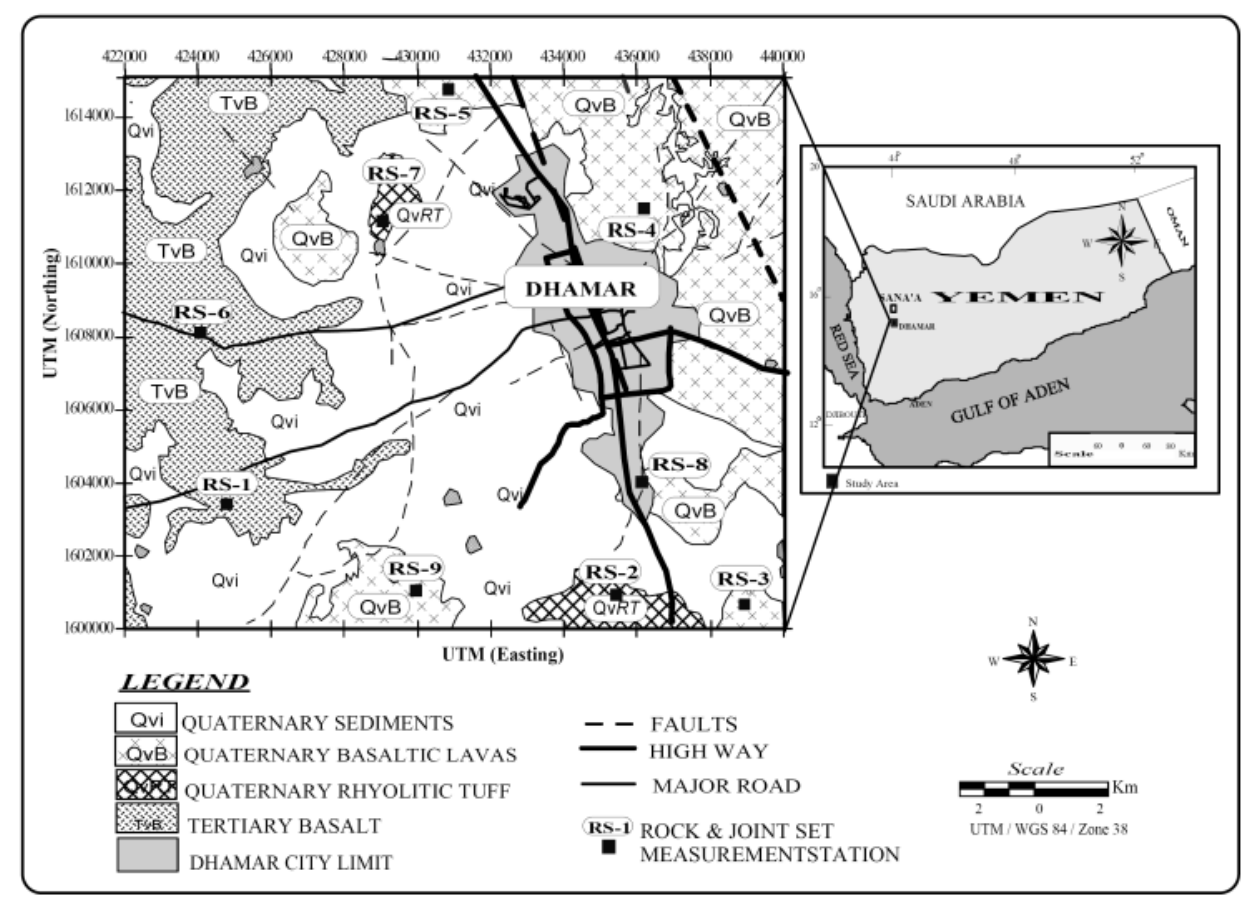

Fig. 1 Location Map of Study Area.

In the study area, the supracrustal rocks are composed of Tertiary basalts, Quaternary rhyolitic tuffs and basalts that are overlain by ignimbrite, volcanic ash flow beds, and alluvial sediments (Fig. 1). Basalt of the Tertiary age is exposed all along the western part whereas the Quaternary basaltic lava flows, which are as abundant as Tertiary basalts, are encountered essentially in the western part of the study area. Rhyolitic tuffs are of limited occurrence and are exposed as isolated patches in the northern and southern parts of the study area. Based on the geological and geotechnical investigation carried out in study area, the central portion is covered with Quaternary ignimbrite ash flows and alluvial sediments with varying thickness from a few meters to 20m (Al-Sanabani and Janardhana, 2011). The eastern part of the study area falls in one of the most Quaternary volcanic activity regions in Yemen (western edge of the Dhamar-Rada
Volcanic Field). A volcanic eruption took place-enveloping Dhamar city from north to south through east. Such recent volcanic activity even occurred in historical times near Dhamar (Fig. 1), where a volcanic eruption was described in 1937 (Plakfer et al., 1987). Fumarolic activity at both Jabal Al-Lisi and Jabal Isbil, east of the Dhamar city, are also reported and the activity is seen even to date. These activities are associated with the rifting of the Red Sea and the Gulf of Aden, which are still spreading, causing accumulations of stresses in the region as a whole. This implies a genetic relationship between seismicity, tectonics, volcanicity and related hydrogeothermal manifestations (Al Aydrus, 1997).

\section{METHODOLOGY}

Seismic hazard assessment is the process of evaluating the design parameters of earthquake ground motion at any site. The 
most design parameters widely used are intensity and peak ground acceleration (PGA). Sometimes peak velocities, peak displacements and response spectrum are also used (Agrawal et al., 2006; Duni and Kuka, 2008). Evaluation of seismic hazard potential in the study area was carried out as per established procedure recommended by Reiter (1990), Kramer (1996; 2009) and Duni \& Kuka (2008) involving the following steps.

1- Collection of data on earlier earthquakes of Yemen and subsetting the data of $100 \mathrm{~km}$ radius of Dhamar city and analysis of earthquake data by statistical methods,

2- Identification of lineaments by visual interpretation of geological maps and Landsat 7 imagery, preparation of lineament map using GIS technique,

3- Construction of seismotectonic map for the study area by using the epicenters of earthquakes and the lineaments,

4- Preparation of isointensity zoning maps of the study area for two epicentral distances,

5- Calculation of PGA and construction of relevant maps.

\section{SEISMICITY AND SEISMOTECTONIC SETTING}

Fig. $2 \mathrm{a}$ and $2 \mathrm{~b}$ show the seismotectonic maps constructed for Yemen and adjacent areas and illustrate the seismotectonic setting of the region. The seismotectonic map (Fig. 2b) drawn by the present investigator for the study area indicated 668 lineaments and the major lineaments trend in NW-SE, NE-SW and SWW-NEE directions that attribute to the general directions of the axial of the Red Sea and the Gulf of Aden. The study area falls in the first zone of Agha (1983) which has been considered as the most hazardous seismic zone in Yemen, fourth zone (highly vulnerable zone) of Alsinawi and Hamad (1991) with seismic intensity up to VIII. Furthermore, the study area is located in the Yemen Plateau Seismogenic Subzone that is prone to the highest dangerous degree from earthquake in the country.

\section{The Earthquake Catalogue}

The seismic data used for the present study is compiled from database of the National Seismological Observatory Center (NSOC). 5157 earthquake events have been recorded in Yemen from 1951 to Sep. 2010 covering the Red Sea, the Gulf of Aden and adjacent areas. The data used for the present study comprised a subset of the earthquake database for $100 \mathrm{~km}$ radius around Dhamar city. 1024 events occurred in the area were used for the preparation of seismotectonic map and among 1024 events, 210 events whose magnitude are $\geq 3 \mathrm{Mb}$ were selected for the purpose of the seismic analysis. The earthquake catalogue of the study area contains information such as, time, coordinates (latitude, longitude), depth of focus, earthquake magnitudes (mb). The obtained catalogue was not complete to use for the objective of the present study, therefore, the important parameters required for seismic assessment such as, surface magnitude (Ms), Earthquake intensity $\left(\mathrm{I}_{\mathrm{o}}\right)$ and the Richter Local Magnitude (M) were calculated. The equations used for calculations of the above parameters are shown in Table 1. The surface magnitude (Ms) was calculated by using the Eq. 1 (Table 1). The earthquake intensity $\left(I_{0}\right)$ is very important factor for seismic hazard evaluation and seismic zonation. Intensity is a number describing the severity of an earthquake in terms of its effects on the earth's surface and on humans and their structures. 

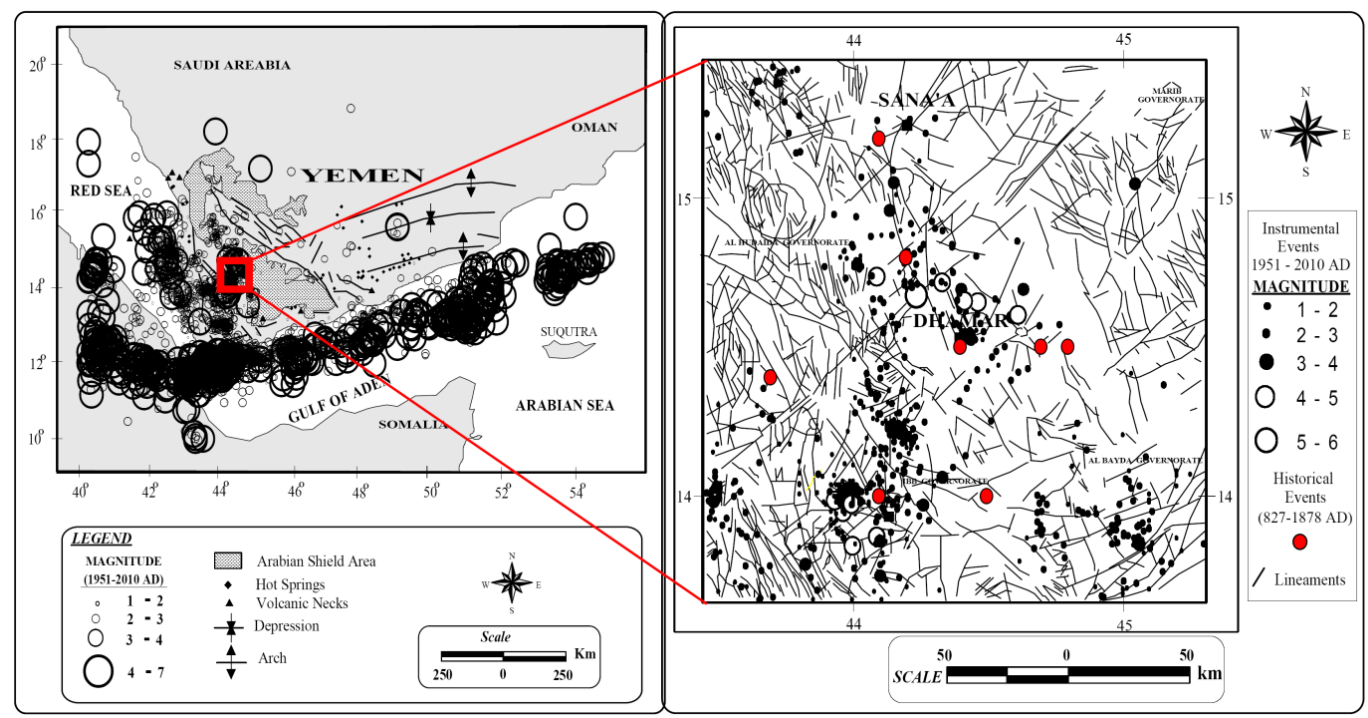

Fig. 2 Seismotectonic Maps Of Yemen (left) and Study Area (right), (Alsanabai, 2011).

\section{The Earthquake Catalogue}

The seismic data used for the present study is compiled from database of the National Seismological Observatory Center (NSOC). 5157 earthquake events have been recorded in Yemen from 1951 to Sep. 2010 covering the Red Sea, the Gulf of Aden and adjacent areas. The data used for the present study comprised a subset of the earthquake database for $100 \mathrm{~km}$ radius around Dhamar city. 1024 events occurred in the area were used for the preparation of seismotectonic map and among 1024 events, 210 events whose magnitude are $\geq 3 \mathrm{Mb}$ were selected for the purpose of the seismic analysis. The earthquake catalogue of the study area contains information such as, time, coordinates (latitude, longitude), depth of focus, earthquake magnitudes (mb). The obtained catalogue was not complete to use for the objective of the present study, therefore, the important parameters required for seismic assessment such as, surface magnitude (Ms), Earthquake intensity $\left(\mathrm{I}_{\mathrm{o}}\right)$ and the Richter Local Magnitude (M) were calculated. The equations used for calculations of the above parameters are shown in Table 1 . The surface magnitude (Ms) was calculated by using the Eq. 1 (Table 1). The earthquake intensity $\left(I_{0}\right)$ is very important factor for seismic hazard evaluation and seismic zonation. Intensity is a number describing the severity of an earthquake in terms of its effects on the earth's surface and on humans and their structures.

Table 1 List of the equations used for present study

\begin{tabular}{|c|c|c|c|}
\hline Parameters & Equations & $\begin{array}{l}\text { Equation } \\
\text { No. }\end{array}$ & References \\
\hline Ms & $M s=1.36 \mathrm{mb}-2.02$ & Eq. 1 & \multirow{2}{*}{ Thenhaus et al., 1989} \\
\hline $\mathbf{I}_{\mathbf{0}}$ & $I_{0}=(M s-0.85) / 0.6$ & Eq. 2 & \\
\hline $\mathbf{M}$ & $M=1+(2 / 3)^{*} I_{0}$ & Eq. 3 & Kumar, 2008 \\
\hline $\mathbf{N}(\mathbf{M})$ & $\log N(M)=a-b * \mathbf{m b}$ & Eq. 4 & $\begin{array}{l}\text { Gutenberg and Richter } \\
\text { (1956) }\end{array}$ \\
\hline $\mathbf{I}_{(\mathbf{r}}$ & $\begin{array}{l}I_{(r)}=4.671+1.51 \mathrm{mb}-2.15 \\
\operatorname{Ln}(R+20)\end{array}$ & Eq. 5 & $\begin{array}{l}\text { Puttonen and Varpasu } \\
\text { (1982) }\end{array}$ \\
\hline
\end{tabular}




\begin{tabular}{|c|c|c|c|}
\hline PGA & PGA $=2000 \mathrm{e}^{0.8 \mathrm{Ms}} \mathrm{r}^{-2}$ & \multirow[t]{2}{*}{ Eq. 6} & \multirow{2}{*}{$\begin{array}{l}\text { Esteira (1974): cited in } \\
\text { NRP (1992) }\end{array}$} \\
\hline $\mathbf{r}$ & $r(k m)=\sqrt{\left(d^{2}+h^{2}+400\right)}$ & & \\
\hline \multicolumn{4}{|c|}{$\begin{array}{l}\text { Ms: Surface Wave Magnitude, Mb: Body wave magnitude, } \boldsymbol{I}_{\boldsymbol{o}}: \text { Modified Mercalli } \\
\text { Intensity Scale (MMI), M: Richter Local Magnitude, } \boldsymbol{N}(\boldsymbol{M}) \text { is the cumulative number } \\
\text { of earthquake per year (Earthquake Magnitude-Recurrence Relationship), } \boldsymbol{a} \& \boldsymbol{b} \\
\text { recurrence parameters, } \boldsymbol{I}_{(r)}: \text { Seismic intensity with distance }(\boldsymbol{R}) \text { from the epicene, PGA } \\
\text { Peak Ground Acceleration: and } \boldsymbol{r}: \text { is the hypocentral distance in } \mathrm{km}\end{array}$} \\
\hline
\end{tabular}

The MMI scale was calculated by using the Eq. 2 (Table 1). For the purpose of seismic assessment, the magnitude (M) was computed by calculating maximum intensity $\left(\mathrm{I}_{\mathrm{o}}\right)$ as shown in Eq. 3 (Table 1). The calculated parameters were used in the interpretation of the seismicity and the PGA for the Dhamar city.

\section{Seismicity of the Study Area}

Based on the statistical analysis, the seismicity of the study region can be classified into three major seismic periods as follows (Fig. 3).

Seismic Period I (1980-1990): This period is characterized by eight earthquake events constituting $0.7 \%$ of the total events that took place after 1982. This decade witnessed high magnitude events such as Dhamar earthquake that took place in the year 1982 $(\mathrm{mb}=6)$. Events of this period have been attributed to the tectonic activity related to the spreading of the Red Sea and Gulf of Aden.

Seismic Period II (1991-2000): This period is characterized by earthquake swarms wherein 697 earthquake events amounting to $68.1 \%$ of the total events occurred in the three decades. The year 1992 witnessed the highest number of events (341 earthquake events amounting to $33.3 \%$ ) followed by the year 1998 which recorded 113 events (11\%). These events were concentrated in the area between Yarim and AlUdyn (Ibb Governorate, located to the south of the study area) (Fig. 3). The earthquake swarms were initiated with Al-Udayn earthquake $(\mathrm{M}=4.4)$ that occurred in 22 Nov. 1991. This event is associated with aftershocks and swarms. The swarm's epicentral distribution showed a depth of focus ranging from 1 to 5 $\mathrm{km}$. The relationship between these events and the major faults has been found very strong (Jaradat, 1993 cited in Alsinawi and Al Aydrus, 1999). A close correlation between igneous activity and regional tectonics along major lineaments are also reported (Abdul Jabbar and Fari, 1993 cited in Alsinawi and Al Aydrus, 1999). The sudden increase in seismicity owing to faults may be an indication of future major events in the region. 


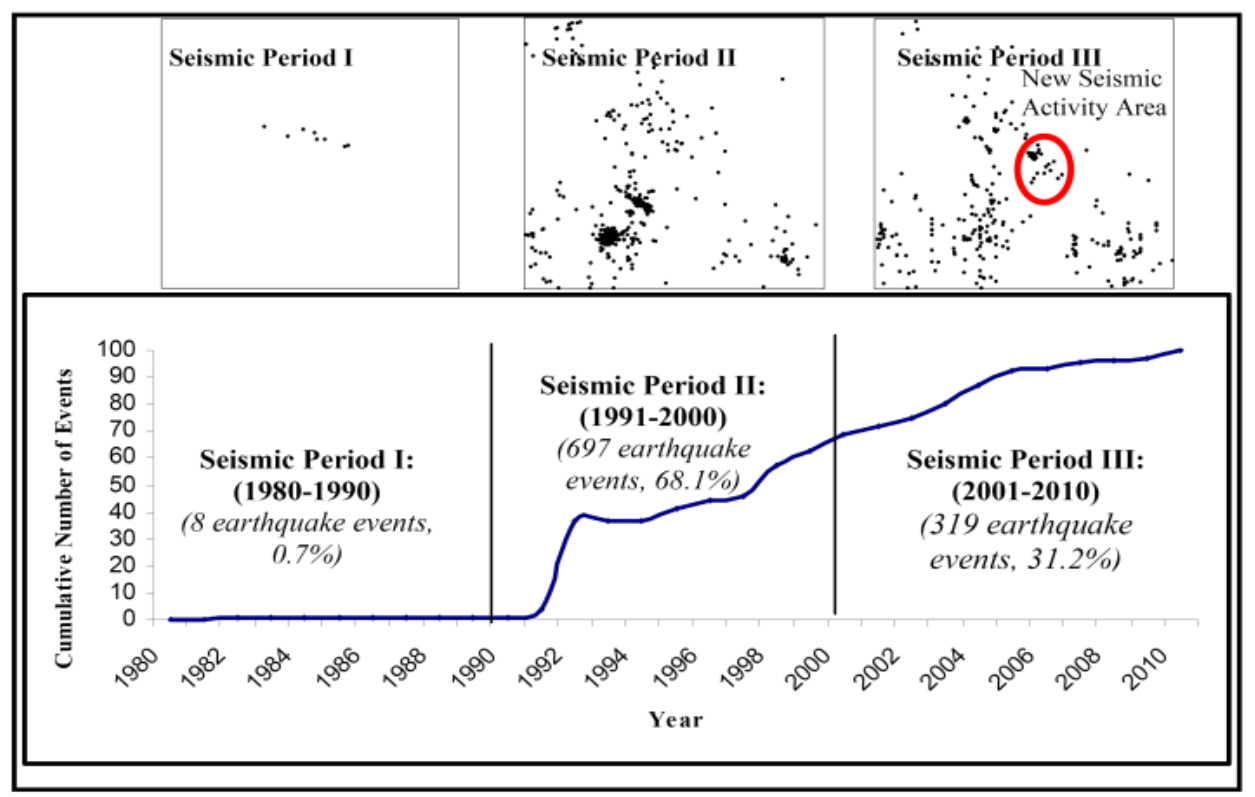

Fig. 3 Top: Maps showing earthquake epicenter of the three seismic periods. Bottom: Cumulative frequency curve of the three seismic periods.

Seismic Period III (2001-2010): The seismicity in this period is relatively low compared with the previous decade (319 earthquake events, 31.2\%). During this decade, seismic activities were concentrated in a new area located at about $5 \mathrm{~km}$ to the southeast of the Dhamar city and situated along the western edge of the DhamarRada'a volcanic field. This event has put the Dhamar city into more vulnerable area for seismicity (Fig. 3). Further, a close correlation between volcanic activity and regional tectonics exist, as the focuses of the most of the earthquake are located at shallow depths.

\section{Earthquake Magnitude-Recurrence Relationship}

The relationship between the number of earthquakes and their magnitude in any time interval is routinely approximated by a Gutenberg and Richter equation (1958, Eq. 4, Table 1). The magnitude recurrence relationship equation used for the study area indicated the values $3.584 / 0.602$ for $a$ and $b$ parameters respectively ( $\mathrm{mb} \geq 3$ : Fig. 4$)$. The $b$ value is classified as low and characterizes the continental rift zones (Miyamura, 1962) which corroborates well with the geological evolution of the study area.

\section{ASSESSMENT OF GEOTECHNICAL SEISMIC HAZARD}

Seismic hazard assessment is the process of evaluating the geotechnical design parameters of earthquake ground motion at any site. The PGA is the most commonly accepted design parameter and is used for the seismic hazard modeling studies (Kayabali, 2002; Duni and Kuka, 2008). In the literature, there are many attenuation relationship laws in terms of intensity, PGA, PGV and PGD, derived for different parts of the world. There is no regional attenuation laws derived for Yemen. The equations by Puttonen and Varpasu (1982) for intensity and PGA by Esteira (1974) were used in Yemen by many researchers during Natural Recourse Project (NRP, 1992) and Alsinawi \& Al Aydrus (1999). Seismic hazard assessment of the study area was carried out using these equations for 210 earthquake events $(\mathrm{mb} \geq 3)$. 


\section{The Isointensity Zoning Map}

The decrease of seismic intensity $\left(\mathrm{I}_{(\mathrm{r})}\right)$ with distance $(\mathrm{R})$ from the epicenter is called attenuation. Attenuation behavior changes from one area to another based on rock and soil types, in addition to their mechanical properties and tectonic setting of the area. Many investigators have presented empirical relationships to describe the attenuation behavior as Gutenberg and Richter (1956) which developed through time. The Isointensity zoning map plotted for the study area is based on the computation of attenuation relationship given by Puttonen and Varpasu (1982, Eq. 5, Table 1). The surface wave magnitude (Ms) in their relationship is replaced by body wave magnitude (mb) relying on Richter (1958) relationship resulting in Eq. 5 (Table 1). Two Isointensity zoning maps were constructed for the study area by using two epicentral distances (R) of zero (Fig. 4-a) and $50 \mathrm{~km}$ (Fig. 4-b) respectively. Based on the Isointensity zoning maps, the study area can be classified into five zones ranging from <IV upto VIII according to the MMI scale (Fig. 4-a: Table 2).

Table 2 Results of Attenuation Relationship Parameters

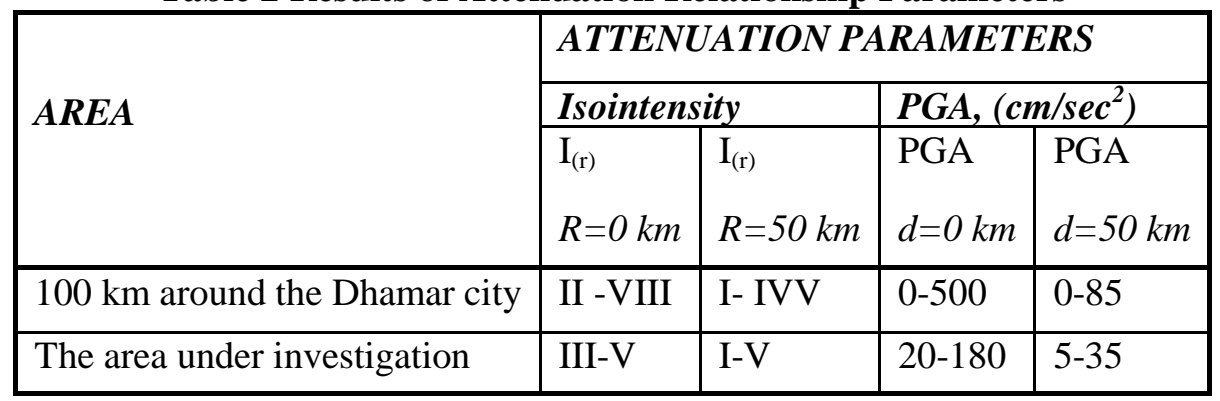

As can be seen from the maps, the area located about $15 \mathrm{~km}$ to the northwest of Dhamar city (Rusaba region) is the highest intensity zone in the area (upto VIII). The epicenter of Dhamar earthquake of 1982 is located within this area, which resulted in this such high seismicity value.

\section{The Peak Ground Acceleration Map}

Eq. 6 in Table 1 was used to calculate the PGA for two attenuation radii of zero and 50 km. Fig. 5-a and Fig. 6-b show the PGA maps of the entire study area using $\mathrm{d}=$ =zero $\mathrm{km}$ and $\mathrm{d}=50 \mathrm{~km}$ respectively. From the figures, it is seen that the PGA values vary from zero to around $500 \mathrm{~cm} / \mathrm{sec}^{2}$ when $\mathrm{d}=$ zero $\mathrm{km}$ and zero to $85 \mathrm{~cm} / \mathrm{sec}^{2}$ at $\mathrm{d}=50$ $\mathrm{km}$. The PGA values for the area in and around Dhamar city vary from 20 to 180 $\mathrm{cm} / \mathrm{sec}^{2}$ (Fig. 5-a). The Rusaba region, located about $15 \mathrm{~km}$ to the northwest of the Dhamar city shows the highest value of PGA attaining more than $500 \mathrm{~cm} / \mathrm{sec}^{2}$, thus, is relatively more vulnerable for future seismic hazard than other regions in and around Dhamar city. 


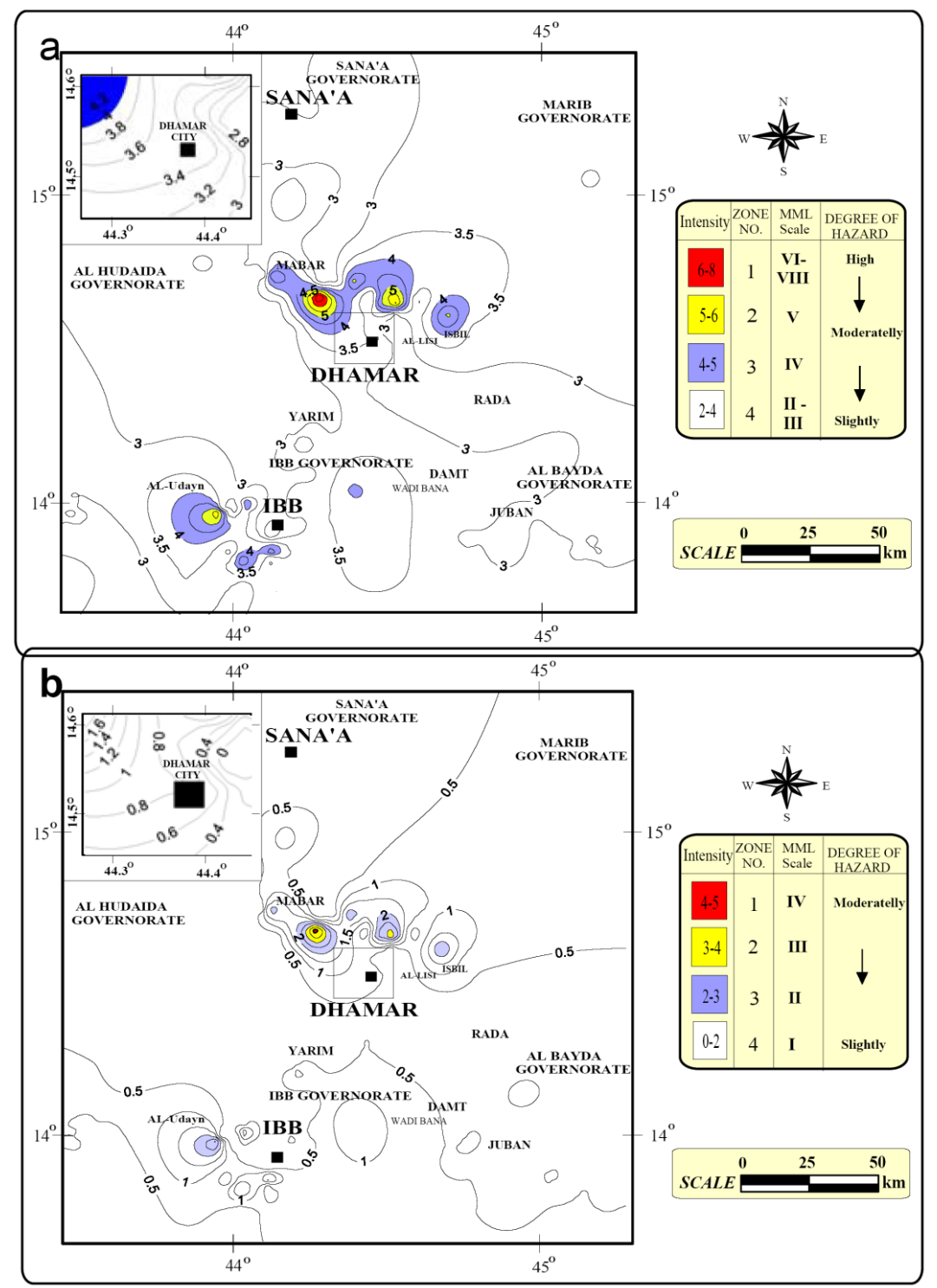

Fig. 4 Isointensity Zoning Maps For The Study Area (upper, R=0 Km And lower, R=50 Km). 

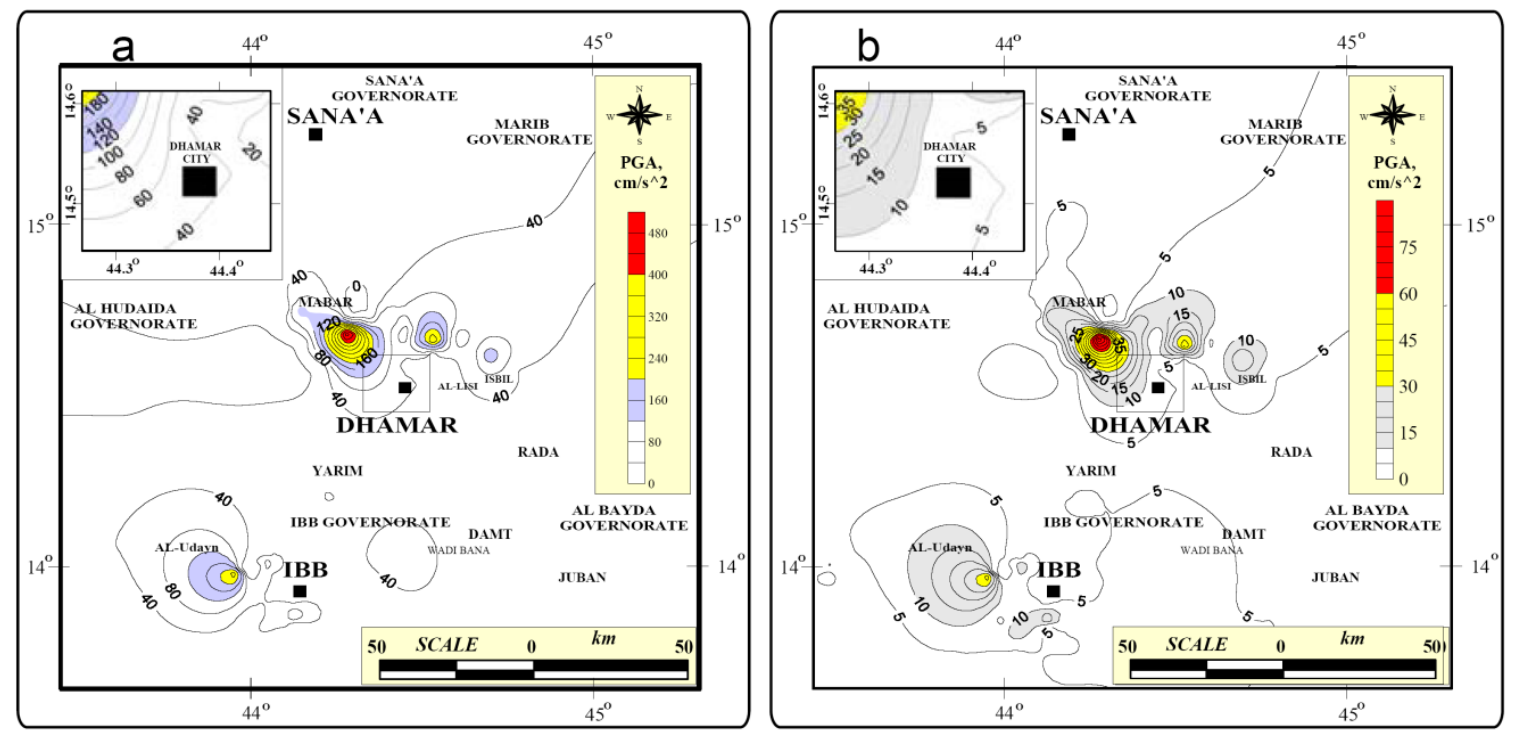

Fig. 5 Peak Ground Acceleration (PGA) Map Constructed For The Study Area (left, D=0 Km And right, $\mathrm{D}=50 \mathrm{Km})$.

\section{CONCLUSIONS}

Geotechnical seismic hazard assessment of the Dhamar region, covering an area of $100 \mathrm{~km}$ radius around Dhamar city is presented, from which the following conclusions are drawn. The geotechnical seismicity of the study region can be classified into three major seismic periods. The seismic activities during the Seismic Period III (2001-2010) were concentrated in a new area, located about $5 \mathrm{~km}$ to the southeast of the Dhamar city and are situated along the western edge of the Dhamar-Rada'a volcanic field. The new seismicity area may be an indication of major events in the study area in the near future. Furthermore, a close correlation between volcanic activity and regional tectonics exists as the focuses of most of the earthquakes are located at shallow depths. The Geotechnical seismic parameters of Isointensity $\left(\mathrm{I}_{(\mathrm{r})}\right)$ was calculated for the study. Results show that most of the study area under investigation is located in the fourth zone (slightly hazardous) and classified as II to III on MMI scale. Two peak ground acceleration (PGA) maps were constructed for the study area. The PGA values for the area under investigation vary from 20 to $180 \mathrm{~cm} / \mathrm{sec}^{2}$. The dynamic stress being developed through time may ultimately lead to major events in the study area in the near future. Geotechnical seismic considerations for foundations of structures should be considered in any design within the study region.

\section{REFERENCES}

Agha, G.A. (1983) Physical Geography of Yemen. Anwar Library, Damascus, (Arabic Text). 558p.

Agrawal, K., and Chawla, J. (2006) Seismic Hazard Assessment for Delhi Region. CURRENT SCIENCE, Vol. 91, No. 12, 25. pp. 1717-1724.

Al Aydrus, A.A. (1997) Seismological Considerations for Yemen. MSc. Thesis, Geology Department, Faculty of Science, Sana'a University, Sana'a, Yemen.

Al Maneefi, A. (1993) Sadah Earthquake of Jan. 11, 1941. Yemen Sem. Seismic 
Hazard Reduction and Disaster Mitigation, Sana'a, Yemen. (Arabic Abst.).

Allen, T. (2010) Geotechnical Design Manual. Washington State, Department of Transportation , WSDOT, M 46-03, 788p.

Al Sanabani, A.H. (2011) Geotechnical Investigations of Soils and Rock Mass Around Dhamar City, Yemen. Unpublished Ph.D.Thesis, Earth Science Departments of Mysore University, India.

Al Sanabani, A.H., and Janardhana, M.R. (2011) Geotechnical Investigations of Quaternary Subsurface Soil in the Western Part of Dhamar City, Republic of Yemen. International Journal of Engineering Research and Technology (IJERT), Vol. 4, Number 2, pp. 221-233.

Al Salim, M. and Saleh, N. (NSOC, 1996) Characteristics of the Recent Earthquake Activity in Yemen, 19p.

Alsinawi, S.A., and Al Aydrus A.A. (1999a) Seismicity of Yemen. Obadi Studies and Publishing Center. Sana'a, Yemen. 297p.

Alsinawi, S.A., and Al Aydrus A.A. (1999b) Seismic Consideration of Yemen. Int. Conf. on Geology of the Arab World, Cairo Univ., Egypt, Vol. 2, pp. 11061129.

Alsinawi, S.A., and Hamed, J.M. (1991) Seismicity of Al-Mashriq Area. Conference on the Geodynamics Development of the Arabian Lithosphere. Yarmuk University, Jordan.

Duni, L., and Kuka, N. (2008) Evaluation of PGA for Tirana City. Acta Geod. Geoph. Hung., Vol. 43(2-3), pp. 209-219.

Esteira, (1974) Cited in the NRP, 1992, Satellite mapping. Technical Report-
Robertson Group PlC and D.G. A Joint (AFESD) and (IJNDP), Ministry of Oil and Mineral Resources, Yemen Republic, 350p.

Girdler, R.W. (1970) The Structure and Evolution of the Red Sea and the Natural of Red Sea-Gulf of Aden and Ethiopia Rift Junction. Tectonophysics, Vol. 10, pp. 597-582.

Gutenberg, B., and Richter, C.F. (1956) Earthquake Magnitude, Intensity, Energy and Acceleration. Bull. Seis. Soc. Am., Vol. 64, pp. 105-145.

Kayabali, K. (2002) Modeling of Seismic Hazard for Turkey Using the Recent Neotectonic Data. Engineering Geology. Vol. 63, pp. 221-232.

Kramer, S.L. (1996) Geotechnical Earthquake Engineering Prentice Hall, Upper Saddle River, New Jersey 07458.

Kramer, S.L. (2009) Geotechnical Earthquake Engineering. Dorling Kindersley, India. 653p.

Kumar, K. (2008) Basic Geotechnical Earthquake Engineering. New Age International, Delhi, India. 142p.

Matthews, D. (1984) Earthquakes: The Vulnerability of Traditional Buildings in the Yemen. In: Evin, A. (Ed), Development, and Urban Metamorphosis Vol. 2, Background Papers. Singapore: Concept Media/The Aga Khan Award for Architecture, pp. 62-69. (Cited in Minissale et al., 2007).

Mckenzie, D.P., Davies D. and Molnar, P. (1970) Plate tectonic of the Red Sea and East Africa: Nature, Vol. 226, pp. 243248.

Minissale A., Mattash M., Vaselli O., Tassi, F., Al-Ganad N., Selmo, E., Shawki, N., Tedesco, D., Poreda, R.,. Ad-Dukhain, A., Hazzae, M., (2007) Thermal Springs, Fumaroles and Gas Vents of Continental 
Yemen: Their Relation with Active Tectonics, Regional Hydrology and the Country's Geothermal Potential, Applied Geochemistry, Vol. 22, pp. 799-820.

Miyamura, S. (1962) Magnitude-Frequency Relation and its Bearings to Geotectonics. Proceeding Japan Academy of Science, 38, pp. 27-30.

Natural Resources Project (NRP, 1992) Satellite Mapping. Technical Report, Robertson Group, PIC and D.G. A Joint (AFESD) and (IJNDP), Ministry of Oil and Mineral Resources, Yemen Republic, pp. 350.

NSOC, (2010) National Seismological Observatory Center, Yemen, web site.

Plafker, G., Agar, R., Asker, A.H., and Hanif, M. (1987) Surface Effect and Tectonic Setting of the 13 December 1982 North Yemen Earthquake. Bull. Seism. Soc. Am. Vol. 77, No. 6, pp. 2018-2037.

Puttonen, J. and Varpasuo, P. (1982). Seismic Risk Analysis for Northern Iraq. Earthquake Engineering and Structural Dynamics, Vol. 10, pp 606-614.

Reiter, L. (1990) Earthquake Hazard Analysis. Columbia University Press, New York.

Richter, C.F. (1958) Elementary Seismology W.H. Freeman and Co., San Francisco 768 p.

Thenhaus, P.C., Algermissen, S.T., Perkins, D.M., Hanson, S.L. and Diment, W.H. (1989) Probabilistic Estimates of the Seismic Ground Motion Hazard in Western Saudi Arabia. US Geological Survey Bull. 1868. Denver, Colorado, USA. 